\title{
Enoxacin inhibits proliferation and invasion of human osteosarcoma cells and reduces bone tumour volume in a murine xenograft model
}

\author{
XUWEN LUO, XUQIANG LIU, QIANYUAN TAO, CONG YAO, FUQIANG WANG, ZHIPING GU, \\ FEILONG LI, XIAOLONG YU, BIN ZHANG, HONGXIAN FAN, MIN DAI and TAO NIE \\ Department of Orthopaedics, The First Affiliated Hospital of Nanchang University, \\ Artificial Joints Engineering and Technology Research Centre of Jiangxi Province, \\ Nanchang, Jiangxi 330006, P.R. China
}

Received January 19, 2020; Accepted April 17, 2020

DOI: 10.3892/ol.2020.11656

\begin{abstract}
Osteosarcoma is the most prevalent primary bone malignancy in children and adolescents. Neoadjuvant chemotherapy combined with surgical resection, the current standard treatment of osteosarcoma, is associated with a 5 -year survival rate of only $\sim 70 \%$. Therefore, it is necessary to identify new, more effective treatment strategies for patients with this lethal disease. Enoxacin is a highly effective broad-spectrum fluoroquinolone antibiotic with low toxicity. The drug inhibits the growth and metastasis of numerous tumour types, but its efficacy has not been studied in osteosarcoma. This study assessed the antitumour effects of enoxacin in osteosarcoma 143B cells and in a murine tumour xenograft model. Enoxacin inhibited the proliferation, invasion and migration of 143B cells, as well as inducing their apoptosis. These effects were thought to be mediated by downregulation of Bcl-xL, Bxl-2, matrix metalloproteinase (MMP)2 and MMP9 expression. Enoxacin also significantly impaired the growth of bone tumours in nude mice without affecting their liver or kidney function, or blood cell count. Collectively, these results indicate that enoxacin is a promising new drug for osteosarcoma that warrants further evaluation in clinical studies.
\end{abstract}

Correspondence to: Professor Tao Nie, Department of Orthopaedics, The First Affiliated Hospital of Nanchang University, Artificial Joints Engineering and Technology Research Centre of Jiangxi Province, 17 Yongwai, Nanchang, Jiangxi 330006, P.R. China E-mail: ncnietao@163.com

Abbreviations: BUN, blood urea nitrogen; Cr, creatinine; DMEM, Dulbecco's Modified Eagle Medium; PBS, phosphate-buffered saline; FBS, foetal bovine serum; PI, propidium iodide; CST, Cell Signalling Technology, Inc.

Key words: enoxacin, osteosarcoma, proliferation, invasion, apoptosis, tumour xenograft model

\section{Introduction}

Osteosarcoma is a malignant bone cancer with high invasiveness and poor prognosis that commonly occurs in children and adolescents $(1,2)$. Osteosarcoma develops from mesenchymal cell lines and is most likely to develop at the ends of long bones, such as proximal tibia and distal femur, because of their abundant blood supply (3). Currently, the most popular treatment for osteosarcoma is neoadjuvant chemotherapy combined with surgical resection; however, the 5-year survival rate with modern protocols has only seen a mild improvement over the past 40 years (from 65 to $70 \%)(4,5)$. The main reason for the poor prognosis is the development of chemoresistance, side effects from chemotherapy and early metastases (6). Therefore, there is an urgent need to identify new, more effective antineoplastic drugs to inhibit the growth and metastasis of osteosarcoma.

Enoxacin is a broad-spectrum, third-generation fluoroquinolone antibiotic with strong bactericidal activity (7). It inhibits the growth of numerous cancer cells types (8-11), including gastric (SNU-638 and SNU-1), colorectal (RKO and HCT-116), liver (HepG2), lung (H23, H1299, and A549), lymphoma (RAJI), and leukaemia (KGla), and is relatively selective for cancer cells, resulting in low toxicity to noncancerous cells $(11,12)$. However, its efficacy and the mechanisms of action in osteosarcoma have not been reported.

This study examined the antitumour effects of enoxacin on osteosarcoma 143B cells in vitro and in a murine xenograft model, and explored the underlying molecular mechanisms.

\section{Materials and methods}

Cell culture and treatment. The human osteosarcoma cell line 143B and human osteoblast hFOB1.19 cell line were purchased from the American Type Culture Collection. The 143B cells were cultured in DMEM (Hyclone GE healthcare) supplemented with 10\% FBS (Gibco; Thermo Fisher Scientific, Inc.) and $100 \mathrm{U} / \mathrm{ml}$ streptomycin and penicillin. The hFOB1.19 cells were maintained in DMEM/F-12 (Hyclone; GE healthcare) containing $15 \%$ FBS. All cells were cultured in a humidified 
atmosphere containing $5 \% \mathrm{CO}_{2}$ at $37^{\circ} \mathrm{C}$. All cells used in the present study were subjected to $>20$ passages and were in exponential cell growth.

Cell proliferation assay. Cells were seeded in 96-well plates $\left(3 \times 10^{3}\right.$ cells/well) and incubated overnight. The following day, enoxacin (Sigma Aldrich; Merck KGaA) diluted in DMEM supplemented with $10 \%$ FBS was added to the wells at $0,3.125,6.25,12.5,25,50$ or $100 \mathrm{mg} / \mathrm{l}$. Viability of $143 \mathrm{~B}$ cells was measured at 24,36 and $48 \mathrm{~h}$, and that of hFOB1.19 cells was assessed at $24 \mathrm{~h}$, using the Cell Counting Kit- 8 (CCK-8; Dojindo Molecular Technologies, Inc.), according to the manufacturer's protocol. The absorbance was measured at $450 \mathrm{~nm}$ using an ELX800 absorbance microboard reader (Bio-Tek Corporation).

Tumour-cell clonogenic assay. Osteosarcoma 143B cells were seeded in a 6 -well culture plate $\left(10^{3}\right.$ cells/well $)$. Enoxacin diluted in DMEM supplemented with $10 \%$ FBS was added to the wells at $0,1.25,2.5,5,10$ or $20 \mathrm{mg} / 1$ and the plates were incubated for 7 days. Following incubation, the culture medium was removed, the cells were fixed in $4 \%$ paraformaldehyde for $15 \mathrm{~min}$ at $4^{\circ} \mathrm{C}$, then stained with $0.1 \%$ crystal violet solution (Beijing Solarbio Science \& Technology Co., Ltd.) for $20 \mathrm{~min}$ at room temperature. The number of colonies (clusters of $>50$ cells) were counted under a light microscope (magnification, x10; Olympus Corporation).

Transwell assays. For the cell invasion assay, 143B cells were suspended in serum-free medium with enoxacin, then $200 \mu 1$ of cell suspension ( $1 \times 10^{4}$ cells) was added on top of Matrigel-coated Transwell chambers $(8-\mu \mathrm{m}$ pore size; Corning, Inc.). The chambers were incubated in $600 \mu \mathrm{l}$ of $10 \%$ serum medium for $18 \mathrm{~h}$. Following incubation, the culture medium in the lower chamber was removed and the cells were washed twice with PBS, then fixed with $4 \%$ paraformaldehyde for $15 \mathrm{~min}$ at $4^{\circ} \mathrm{C}$, and stained with $0.05 \%$ crystal violet solution for $20 \mathrm{~min}$ at room temperature. A cotton swab was used to remove the cells that had not passed through the membrane, while the transmembrane cells were imaged (magnification, $\mathrm{x} 10$ ) and counted in 5 microscopic fields using a light microscope (Olympus Corporation).

The cell migration assay was performed under similar experimental conditions as the invasion assay but using non-Matrigel coated cell culture inserts.

Annexin V/propidium iodide (PI) apoptosis assay. Osteosarcoma 143B cells were seeded in 6 -well plates $\left(10^{5}\right.$ cells/well $)$. The next day, enoxacin diluted in DMEM containing 10\% FBS was added to the wells at $0,5,10$ or $20 \mathrm{mg} / \mathrm{l}$ and the plates were incubated for $24 \mathrm{~h}$. Following incubation, the supernatants and adherent cells were collected and Annexin $\mathrm{V}$ and PI staining was performed using the $\mathrm{YF}^{\circledR} 488$ Annexin V and PI Apoptosis kit (US Everbright ${ }^{\circledR}$ Inc.), according to the manufacturer's protocol. Briefly, the cells were resuspended in Annexin V binding buffer $(100 \mu \mathrm{l})$ before Annexin V (4-5 $\mu \mathrm{l})$ and PI (1-2 $\mu \mathrm{l})$ working solutions were added to each tube. The tubes were set on ice and incubated in the dark for $15 \mathrm{~min}$. Apoptotic cells were quantified using a flow cytometer (BD FACSCanto II; Becton, Dickinson and Company) and the apoptosis rates were calculated using FlowJo 7.6 software (Tree Star, Inc.).

Western blot analysis. Osteosarcoma 143B cells were seeded in 6-well plates $\left(3 \times 10^{5}\right.$ cells/well) and treated with enoxacin $(0,10$ or $20 \mathrm{mg} / \mathrm{l})$ for $24 \mathrm{~h}$, then washed twice with PBS and lysed with RIPA lysis buffer $(50 \mathrm{mM}$ Tris- $\mathrm{HCl}, 150 \mathrm{mM} \mathrm{NaCl}$, $5 \mathrm{mM}$ EDTA, $1 \%$ Triton X-100, $1 \mathrm{mM}$ sodium fluoride, $1 \mathrm{mM}$ sodium vanadate, $1 \%$ deoxycholate, and protease inhibitor cocktail; Beyotime Institute of Biotechnology). The cells were collected into centrifuge tubes using a cell scraper and lysed on ice for $30 \mathrm{~min}$, with frequent shaking to ensure full lysis. The cells were centrifuged at $12,000 \mathrm{x} \mathrm{g}$ at $4^{\circ} \mathrm{C}$ for $15 \mathrm{~min}$ before the supernatant was collected and the total protein concentration was determined using the bicinchoninic acid method (Beyotime Institute of Biotechnology).

Following the instructions for the use of the electrophoresis instrument (Bio-Rad Laboratories, Inc.), a total of $20 \mu \mathrm{l}$ protein $(1.5 \mu \mathrm{g} / \mu \mathrm{l})$ from each sample were separated by $10 \%$ SDS-PAGE and then transferred to PVDF membranes (EMD Millipore). The membranes were blocked with 5\% skimmed milk (Becton, Dickinson and Company) for $1 \mathrm{~h}$ at room temperature before they were probed with primary antibodies [rabbit anti-human matrix metalloproteinase (MMP)2 monoclonal antibody; Cell signalling Technology, Inc. (CST); cat. no. 87809S; 1:1,000; rabbit anti-human MMP9 monoclonal antibody; CST; cat. no. 13667S; 1:1,000; rabbit anti-human Bcl-xL monoclonal antibody; CST; cat. no. 2764S; 1:1,000; rabbit anti-human Bcl-2 monoclonal antibody; CST; cat. no. 4223S, 1:1,000; rabbit anti-human GAPDH; CST; cat. no. $5174 \mathrm{~S} ; 1 ; 1,000]$ at $4^{\circ} \mathrm{C}$ overnight. The following day, the membranes were washed three times with TBS-T $(0.05 \%$ Tween-20; Boster Biological Technology) and then the second antibody (goat anti-rabbit IgG; HRP-linked antibody; CST; $7074 \mathrm{~S} ; 1: 2,000)$ was incubated for $2 \mathrm{~h}$ at room temperature. Immunoreactive protein bands were detected by enhanced chemiluminescence (ECL kit, TransGen Biotech Co., Ltd.) according to the manufacturer's protocol.

Tumour xenograft model. A total of 20 4-week-old female BALB/c-nu/nu nude mice ( $19.0 \mathrm{~g})$, were obtained from Shrek Jingda Experimental Animal Centre (Hunan, China) and raised in a laminar mouse house, with $50 \pm 5 \%$ humidity, $24 \pm 2{ }^{\circ} \mathrm{C}$ and a 12-h light/dark cycle. The mice were fed standard rodent food and mineral water. Osteosarcoma $143 \mathrm{~B}$ cells were diluted with PBS (up to a density of $1 \times 10^{7}$ cells $/ \mathrm{ml}$ ) and $100 \mu \mathrm{l}$ of cell suspension was injected into the tibial plateau of anesthetized nude mice. Subsequently, the mice were randomly divided into 4 groups: Blank control, saline $(\mathrm{NaCl})$, low enoxacin concentration (enoxacin diluted with $\mathrm{NaCl}, 4 \mathrm{mg} / \mathrm{kg} / \mathrm{d}$ ), and high enoxacin concentration (enoxacin diluted with $\mathrm{NaCl}$, $8 \mathrm{mg} / \mathrm{kg} / \mathrm{d}$ ), with 5 mice in each group. One week later, the mice were injected intraperitoneally with $\mathrm{NaCl}$ or enoxacin every day for 3 weeks. Tumour volume (measured with the Vernier calliper, $\mathrm{V}=$ length $\mathrm{x}$ width ${ }^{2} \mathrm{x} 0.5$ ) and body weight (measured electronically) of the mice were recorded every week. At the end of the study period, the mice were euthanised and the tumours were dissected to measure their volume and weight. Cardiac blood $(200 \mu \mathrm{l})$ was collected to evaluate liver and kidney function. 

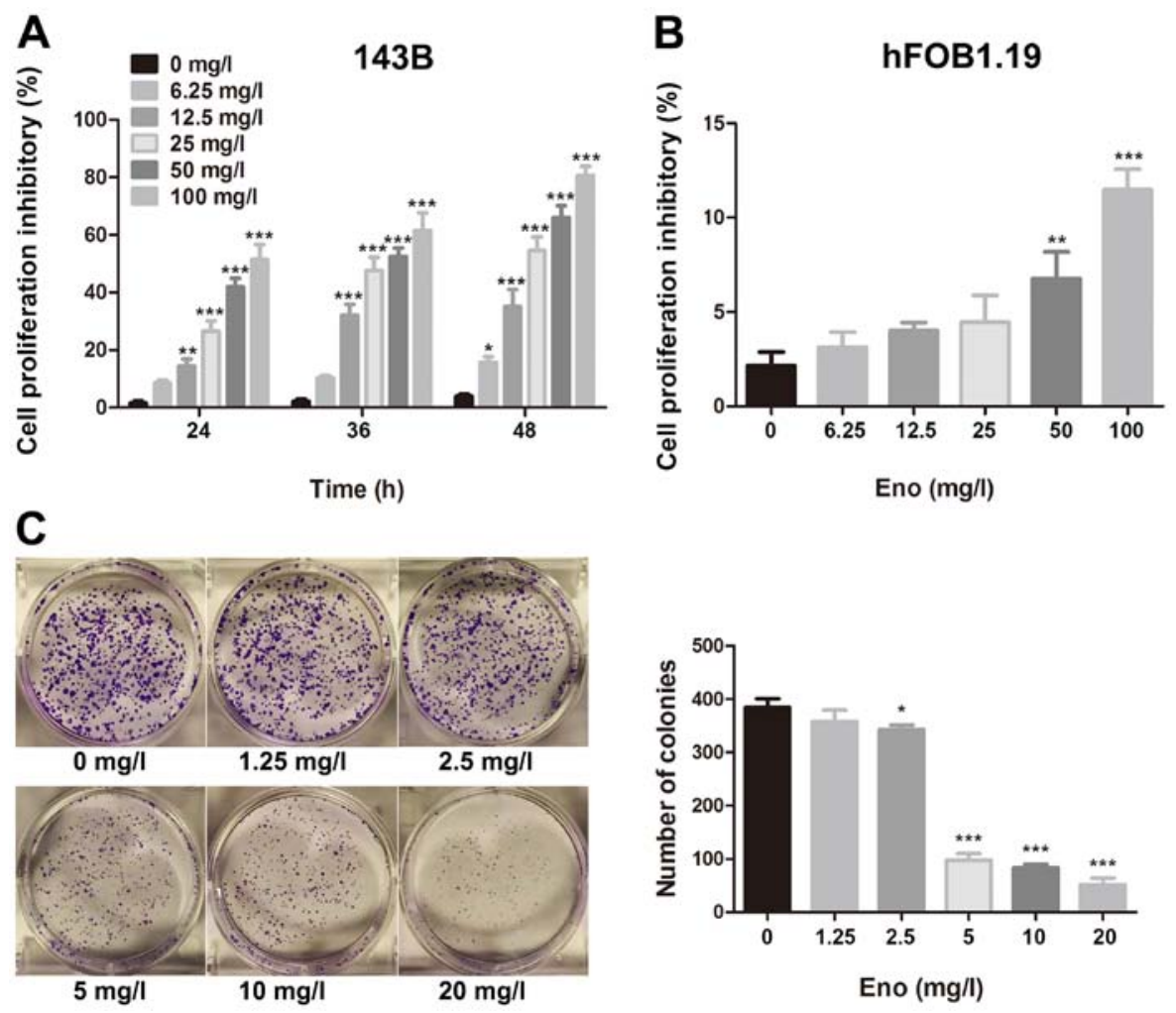

Figure 1. Enoxacin inhibits the proliferation and clonogenic ability of human osteosarcoma cells. (A) 143B cells and (B) hFOB1.19 cells were treated with increasing concentrations of Eno and incubated for up to 48 and 24 h, respectively. Cell viability was assessed using the Cell Counting Kit-8 assay. Eno inhibited the proliferation of 143B cells in a time- and dose-dependent manner, but did not affect the proliferation of hFOB1.19 cells at up to $25 \mathrm{mg} / \mathrm{l}$. (C) $143 \mathrm{~B}$ cells were treated with Eno and incubated for 7 days. Eno impaired the colony-forming ability of 143B cells in a concentration-dependent manner. The results are expressed as the mean $\pm \mathrm{SD}$ of three experiments. ${ }^{*} \mathrm{P}<0.05,{ }^{* *} \mathrm{P}<0.01$ and ${ }^{* * *} \mathrm{P}<0.001$ vs. control $(0 \mathrm{mg} / \mathrm{l}$ Eno). Eno, enoxacin.

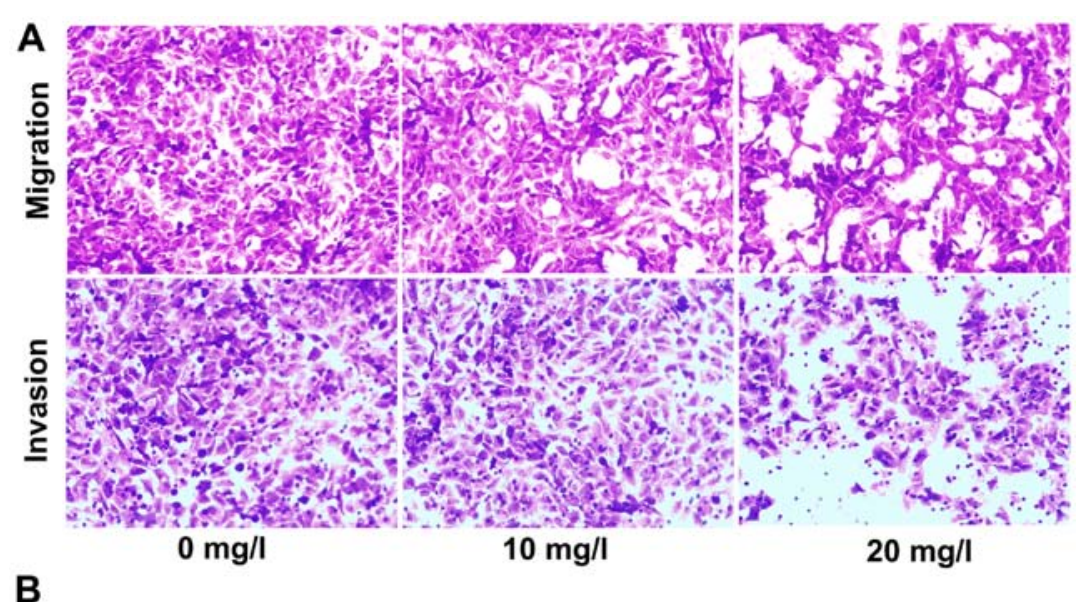

B
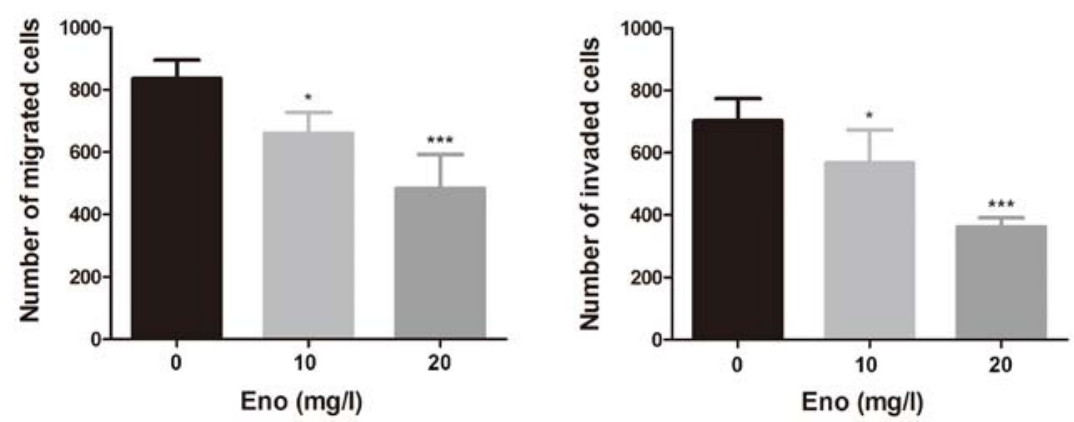

Figure 2. Eno impairs the migratory and invasive abilities of human osteosarcoma cells. (A) 143B cells were treated with Eno for $18 \mathrm{~h}$, then stained with $0.05 \%$ crystal violet and visualised under a phase contrast microscope (magnification, x10). (B) The migratory and invasive abilities of $143 \mathrm{~B}$ cells were evaluated by counting the number of migrated and invaded cells. The results are expressed as the mean \pm SD of three experiments. ${ }^{*} \mathrm{P}<0.05$ and ${ }^{* * *} \mathrm{P}<0.001 \mathrm{vs}$. control $(0 \mathrm{mg} / \mathrm{l} \mathrm{Eno})$. Eno, enoxacin. 

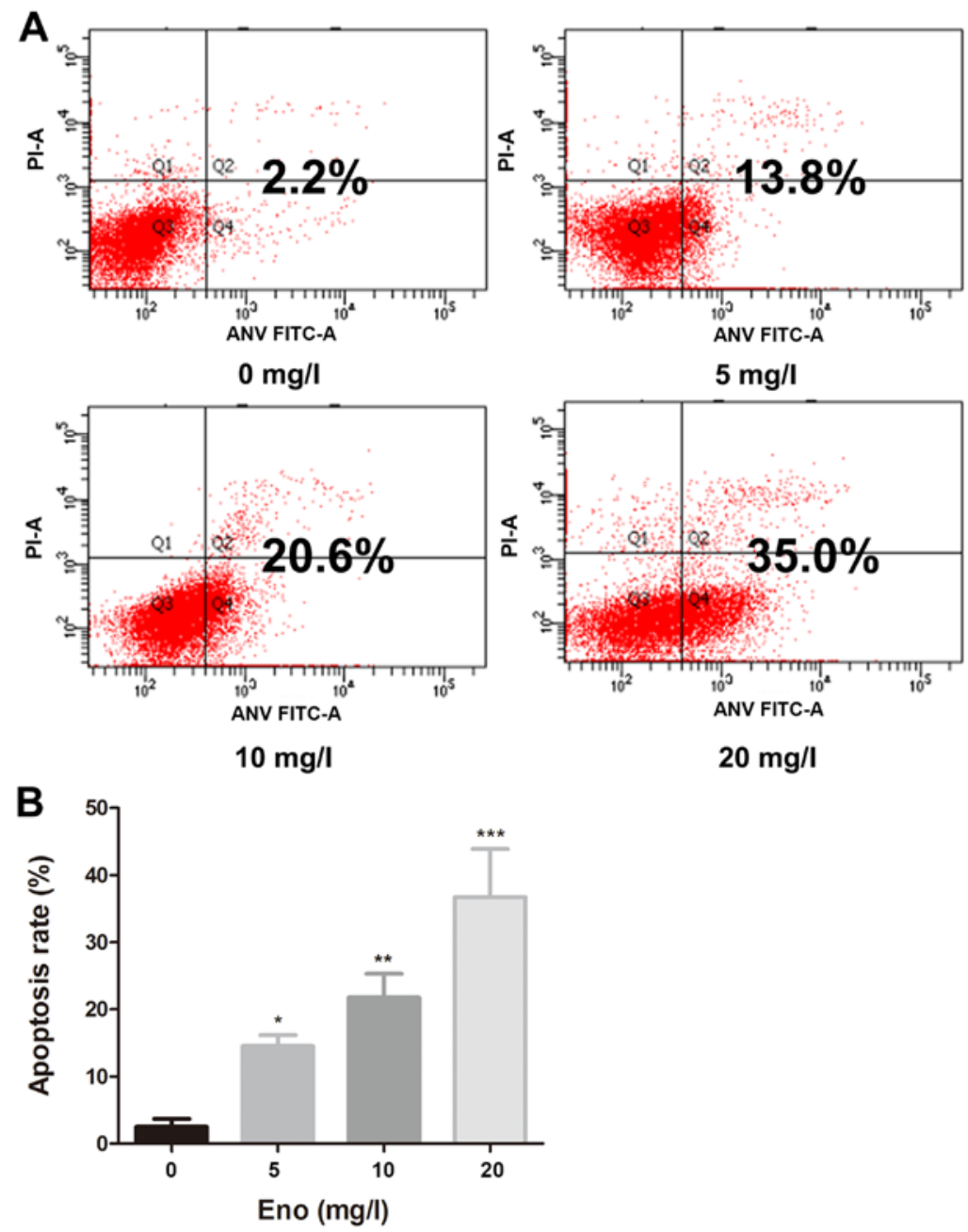

Figure 3. Eno increases apoptosis of human osteosarcoma cells. (A) 143B cells were treated with Eno for $24 \mathrm{~h}$, before apoptosis was assessed by flow cytometry using Annexin V/PI staining. (B) The percentage of apoptotic cells was quantified. The results are expressed as the mean \pm SD of three experiments. "P<0.05, ${ }^{* *} \mathrm{P}<0.01$ and ${ }^{* * * *} \mathrm{P}<0.001$ vs. control $(0 \mathrm{mg} / 1$ Eno). Eno, enoxacin; $\mathrm{PI}$, propidium iodide.

Statistical analyses. The data were analysed by GraphPad Prism 5.0 software. Statistical significance between groups was analysed using student's t-tests or ANOVA followed by the Tukey test. The results are presented as means $\pm \mathrm{SD}$. All the experiments were performed at least three times. $\mathrm{P}<0.05$ was considered to indicate statistically significant differences between groups.

\section{Results}

Enoxacin inhibits the proliferation of $143 B$ cells but not that of hFOB1.19 cells. A CCK-8 assay was used to assess the antiproliferative effect of enoxacin on human osteosarcoma and osteoblast cell lines. Enoxacin inhibited the proliferation of 143B cells in a time- and concentration-dependent manner (Fig. 1A), without a significant effect on the proliferation of hFOB1.19 cells at up to $25 \mathrm{mg} / \mathrm{l}$ (Fig. 1B). The present results indicate that enoxacin is effective and selective towards human osteosarcoma cells and exhibits no obvious toxicity towards normal osteoblasts at up to $25 \mathrm{mg} / \mathrm{l}$ (within the concentration range used in this study).

Enoxacin impairs the colony-forming ability of $143 B$ cells. The effect of enoxacin on the colony-forming ability of single osteosarcoma 143B cells was assessed with a clonogenic assay. In the control group $(0 \mathrm{mg} / \mathrm{l})$ and low enoxacin concentration group $(1.25 \mathrm{mg} / \mathrm{l})$, a large number of colonies formed within one week of culture (colony formation rate $\geq 80.34 \%$ ). Increasing enoxacin concentration was associated with decreasing size and number of colonies, indicating that the drug inhibits 143B cell proliferation and colony formation in a dose-dependent manner (Fig. 1C).

Enoxacin inhibits the migration and invasion of $143 B$ cells. The effect of enoxacin on the migration and invasion of osteosarcoma 143B cells was evaluated using Transwell assays. The drug significantly impaired the migratory and invasive abilities of 143B cells in a dose-dependent manner (Fig. 2), suggesting that it could inhibit the metastasis of osteosarcoma.

Enoxacin stimulates apoptosis of $143 \mathrm{~B}$ cells. Flow cytometric analysis with Annexin V/PI staining was performed to investigate whether enoxacin inhibited the growth of osteosarcoma 143B cells by stimulating apoptosis. Enoxacin-treated cells exhibited a significantly increased rate of apoptosis compared with that of the control cells (Fig. 3). 

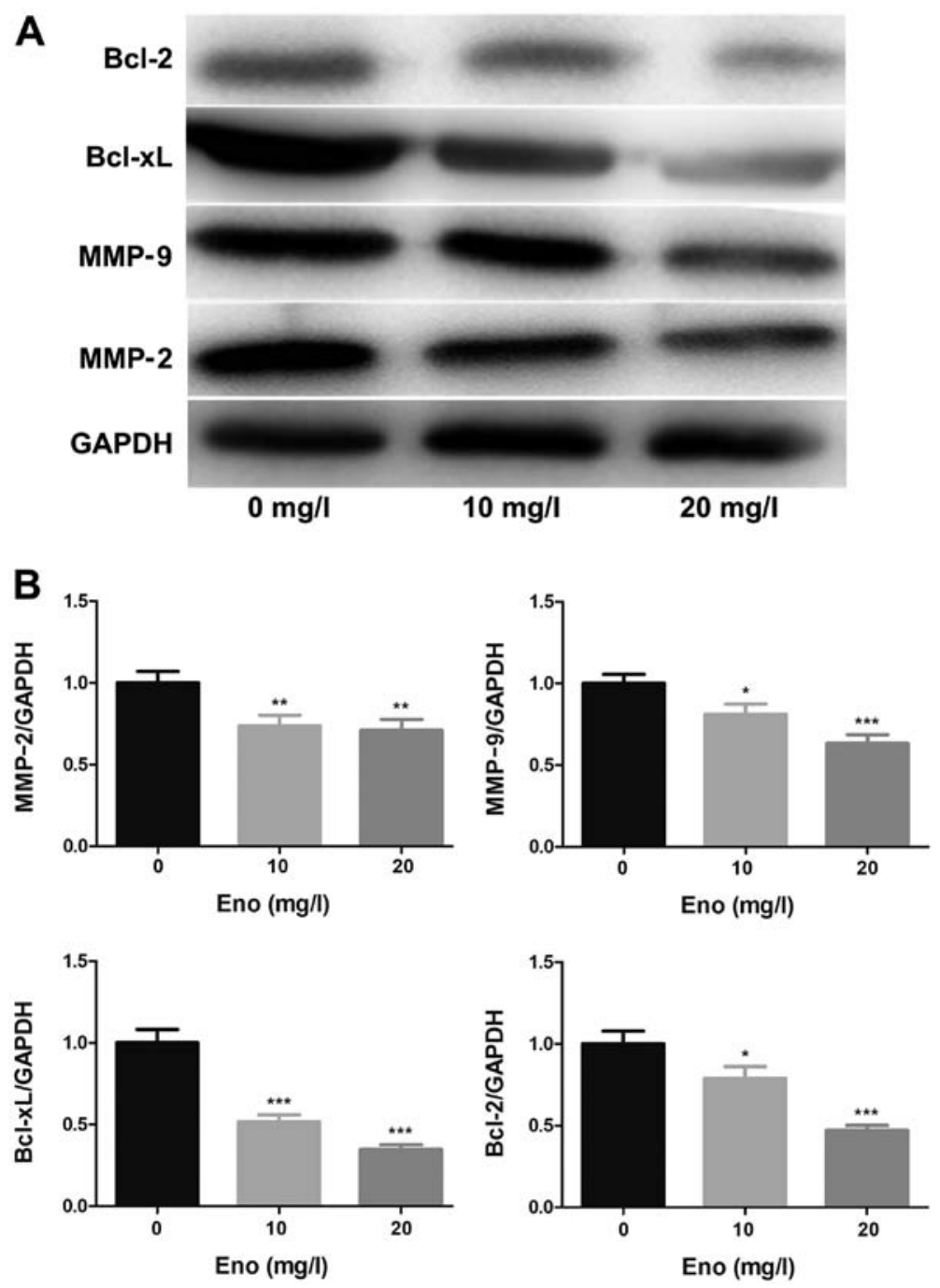

Figure 4. Eno downregulates the expression of MMPs and Bcl-2 family proteins in human osteosarcoma cells. (A) Western blot of protein expression in control and Eno-treated cells. (B) Eno downregulated the expression of MMPs (MMP2 and MMP9) and apoptosis-related proteins (Bcl-xL and Bcl-2) in 143B cells. GAPDH was used as the internal control. The results are expressed as the mean \pm SD of three experiments. ${ }^{*} \mathrm{P}<0.05,{ }^{* * *} \mathrm{P}<0.01$ and ${ }^{* * * *} \mathrm{P}<0.001$ vs. control (0 mg/l Eno). MMP, matrix metalloproteinases; Eno, enoxacin.

Enoxacin downregulates the expression of $M M P 2, M M P 9$, $B c l-x L$ and $B c l-2$ in $143 B$ cells. To explore the molecular mechanisms underlying the antitumour effects of enoxacin, the expression of MMPs (MMP2 and MMP9) and Bcl-2 family proteins (Bcl-xL, Bcl-2) in enoxacin-treated osteosarcoma 143B cells were assessed using western blot analysis. Expression levels of MMP2, MMP9, Bcl-xL and Bcl-2 were significantly decreased in enoxacin-treated cells compared with that in control cells (Fig. 4). These observations suggest that the pro-apoptotic and anti-invasion effects of enoxacin are mediated by downregulation of $\mathrm{Bcl}-2$ family proteins and MMP expression.

Enoxacin impairs the growth of osteosarcoma in vivo. A xenograft tumour model with 143B cells was established in nude mice to assess the effect of enoxacin on tumour growth. The tumour volume and weight were significantly decreased in enoxacin-treated mice compared with in untreated mice. In contrast, there were no significant differences in tumour volume or weight between the $\mathrm{NaCl}$ group and the control group (Fig. 5A-C). Body weight of the mice in the treatment groups did not differ significantly from that of control mice during the study period (Fig. 5D). These data show that enoxacin hinders the development of osteosarcoma and has no obvious drug toxicity in nude mice.

Side effects of enoxacin in vivo. Circulating levels of liver enzymes (alanine transaminase and aspartate aminotransferase) and renal function markers [blood urea nitrogen (BUN) and creatinine $(\mathrm{Cr})]$ were measured in nude mice heart blood to evaluate hepatotoxicity and nephrotoxicity following enoxacin treatment. The functions of the liver and kidney were normal in all groups (Table I). Erythrocyte, leukocyte and platelet counts of the mice were within normal limits, indicating that enoxacin has no obvious haematological side effects within the dosage range tested (Table II).

\section{Discussion}

Osteosarcoma is a bone cancer that originates from mesenchymal tissue and exhibits high degree of invasiveness, malignancy, and poor prognosis; its incidence is reported 
A

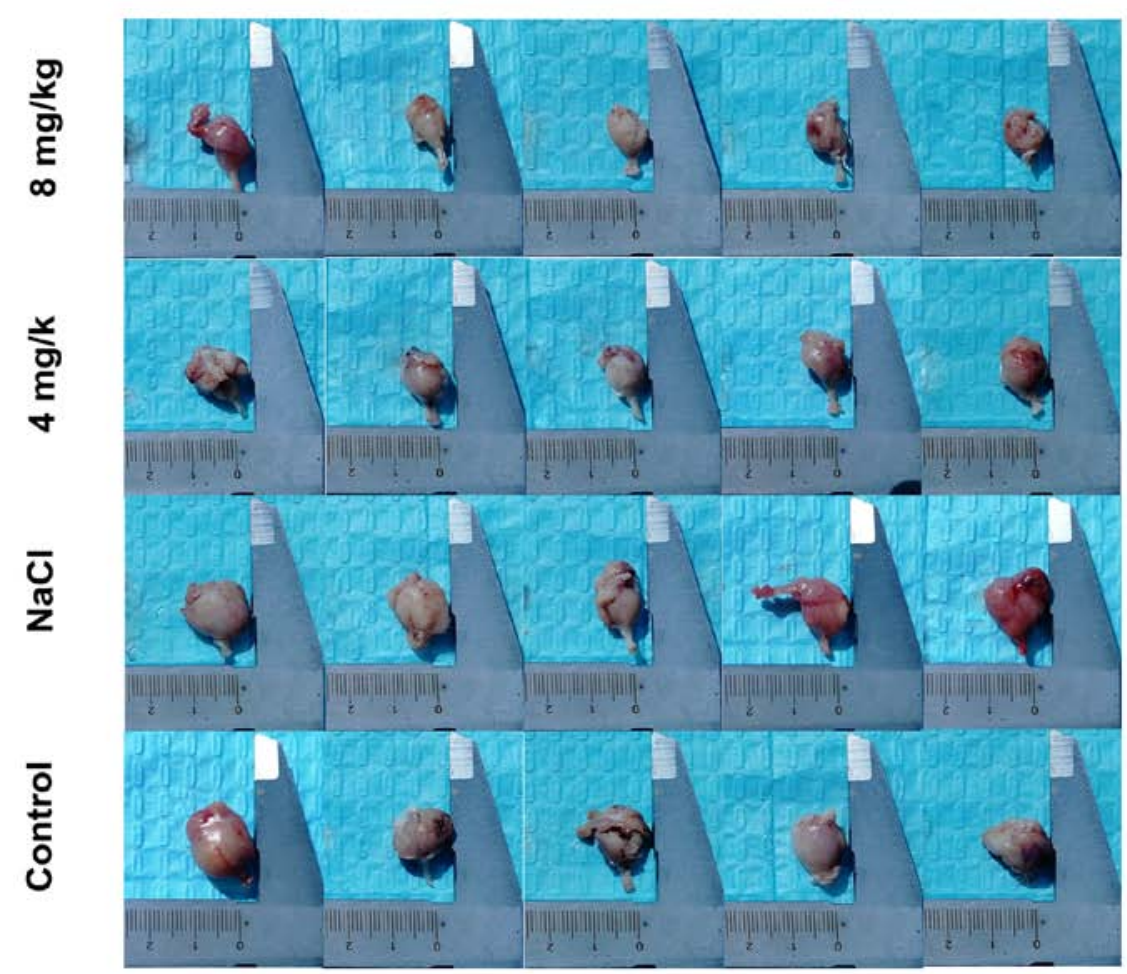

B

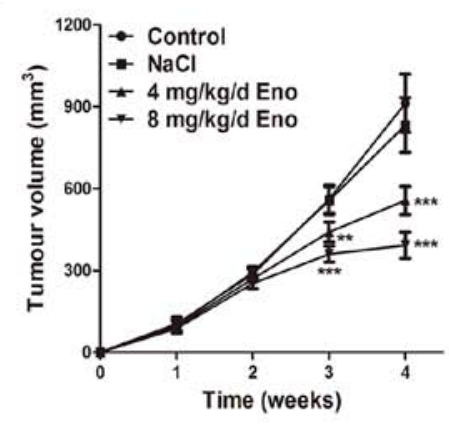

C

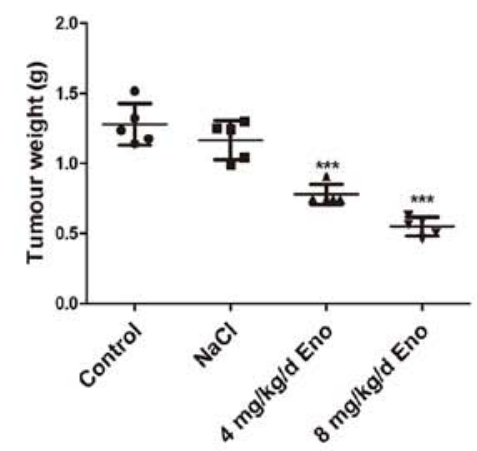

D

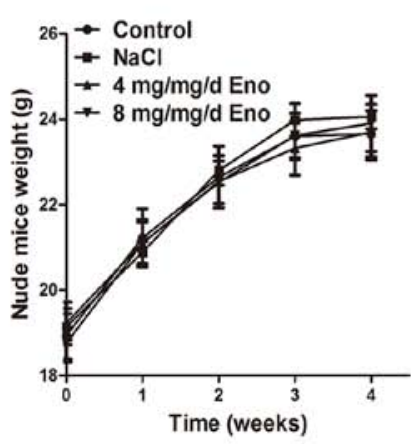

Figure 5. Enoxacin inhibits the growth of osteosarcoma in vivo without obvious toxicity. (A) The size of tumours in each group. (B) The tumour volume was significantly smaller in the treatment groups than in the control group. (C) The tumour weight was significantly lower in the treatment groups than in the control group. (D) There were no significant differences in body weight between the groups. ${ }^{* *} \mathrm{P}<0.01$ and ${ }^{* * *} \mathrm{P}<0.001 \mathrm{vs}$. control ( $0 \mathrm{mg} / \mathrm{kg} / \mathrm{d}$ Eno).

to be $\sim 5$ cases per million persons per year. The disease is particularly prevalent among children and adolescents $(13,14)$. At present, the mainstream treatment protocol for patients with osteosarcoma is a combination of neoadjuvant chemotherapy and surgery, and although the prognosis has improved (14-17), the 5-year overall survival rate is still unsatisfactory (18). The early detection rate of osteosarcoma is low and pulmonary metastases are often discovered at diagnosis, which complicates treatment $(19,20)$. Thus, it is necessary to explore the molecular mechanisms of metastasis and invasion of osteosarcoma to identify new avenues for the treatment of this lethal disease.

Enoxacin is a highly effective broad-spectrum fluoroquinolone antibiotic with low toxicity (12). Several studies have confirmed that, in addition to its antibacterial properties, enoxacin also displays antitumour activity (8-11). Thus, its effect on the proliferation, migration and invasion of human osteosarcoma 143B cells was investigated. The present results indicate that enoxacin could prevent metastasis and promote apoptosis in osteosarcoma, and improve patient survival.

Metastasis, a biological characteristic of malignant tumours, is a dynamic process that involves the spread of tumour cells from the primary site to the surrounding or distant tissue. Early lung metastasis by hematogenous dissemination is the cause of high mortality in osteosarcoma (21). In this study, it was found that enoxacin blocked the migration and invasion of 143B cells, highlighting its potential in the prevention of osteosarcoma metastasis.

The formation, progression, invasion and metastasis of malignant tumours are often accompanied by changes in the expression of extracellular matrix (ECM) components and their cell surface receptors. The degradation of ECM by 
Table I. Effect of enoxacin on liver and kidney function in nude mice.

\begin{tabular}{lccrrr}
\hline Enoxacin & $\mathrm{n}$ & ALT $(\mathrm{u} / \mathrm{l})$ & \multicolumn{1}{c}{ AST $(\mathrm{u} / \mathrm{l})$} & BUN $(\mathrm{mmol} / \mathrm{l})$ & $\mathrm{Cr}(\mathrm{mmol} / \mathrm{l})$ \\
\hline Control & 5 & $32.05 \pm 3.03$ & $98.96 \pm 13.10$ & $5.79 \pm 1.00$ & $21.23 \pm 2.30$ \\
$\mathrm{NaCl}$ & 5 & $29.24 \pm 3.37$ & $106.04 \pm 17.55$ & $6.51 \pm 0.90$ & $21.63 \pm 3.00$ \\
$4 \mathrm{mg} / \mathrm{kg} /$ day & 5 & $29.65 \pm 3.55$ & $98.93 \pm 12.72$ & $5.56 \pm 0.59$ & $22.82 \pm 3.06$ \\
$8 \mathrm{mg} / \mathrm{kg} /$ day & 5 & $31.43 \pm 3.00$ & $100.04 \pm 21.50$ & $5.97 \pm 1.96$ & $22.62 \pm 3.82$ \\
\hline
\end{tabular}

No difference was observed in the ALT, AST, BUN and $\mathrm{Cr}$ among the groups $(\mathrm{P}>0.05)$. ALT, alanine aminotransferase; AST, aspartate transaminase; BUN, blood urea nitrogen; $\mathrm{Cr}$, creatinine.

Table II. Effect of enoxacin on blood cell count of nude mice.

\begin{tabular}{lcccc}
\hline Enoxacin & $\mathrm{n}$ & Erythrocyte $\left(\mathrm{x} 10^{12} / \mathrm{l}\right)$ & Leukocyte $\left(\mathrm{x} 10^{9} / \mathrm{l}\right)$ & Platelet $\left(\mathrm{x} 10^{9} / \mathrm{l}\right)$ \\
\hline Control & 5 & $8.18 \pm 0.44$ & $4.98 \pm 1.03$ & $803.18 \pm 85.72$ \\
$\mathrm{Nacl}$ & 5 & $8.12 \pm 0.83$ & $4.32 \pm 0.82$ & $743.52 \pm 108.70$ \\
$4 \mathrm{mg} / \mathrm{kg} /$ day & 5 & $7.96 \pm 0.69$ & $4.56 \pm 0.64$ & $789.76 \pm 70.71$ \\
$8 \mathrm{mg} / \mathrm{kg} /$ day & 5 & $8.46 \pm 0.54$ & $4.66 \pm 0.70$ & $793.46 \pm 94.11$
\end{tabular}

No difference was observed in the blood cell counts among the groups $(\mathrm{P}>0.05)$.

MMPs is a key step in the invasion and metastasis processes in human cancers, and increased secretion and activity of MMPs are implicated in numerous types of malignant tumours $(22,23)$. MMP2 and MMP9 are important members of the MMP family and inhibition of their expression is a strategy for reducing the invasion and metastasis of osteosarcoma $(24,25)$. The current western blot analysis showed that enoxacin treatment downregulated the expression of MMP2 and MMP9 in 143B cells, which could be an effective way to inhibit osteosarcoma metastasis.

Apoptosis is a physiological phenomenon that is necessary for normal growth, development and maintenance of cellular homeostasis, which also plays a central role in tumour development (26). The present results demonstrated that enoxacin stimulated apoptosis in 143B cells and decreased tumour volume and weight in the xenograft model of osteosarcoma. Therefore, enoxacin might block tumour growth in osteosarcoma.

Apoptosis is a complex process that is tightly regulated by multiple genes (27). Bcl-2 family proteins can prevent the release of cytochrome $\mathrm{C}$ from mitochondria to the cytoplasm, thus inhibiting apoptosis $(28,29)$. Bcl-2 and $\mathrm{Bcl}-\mathrm{xL}$ are the main anti-apoptotic molecules among the members of the Bcl-2 family; reducing their protein levels can promote apoptosis of tumour cells. In the current study, enoxacin downregulated protein expression of both Bcl-2 and Bcl-xL to trigger the mitochondrial apoptosis pathway in 143B cells.

In the mouse study, the tumour volume and weight were decreased in the enoxacin-treated group compared with in the untreated group. However, mean body weights did not differ between enoxacin-treated and untreated mice. Furthermore, there was no evidence of disturbed liver or kidney function, or altered blood cell count in enoxacin-treated mice, which confirms that the drug has good antitumour efficacy without obvious toxic effects in vivo.

The current study describes the pharmacological activities of enoxacin against osteosarcoma and explores its potential as a novel approach to the treatment of this disease. The use of fluoroquinolones, such as enoxacin, is limited in children because of their potential to cause cartilage dysplasia. Nevertheless, it is estimated that in the Unites States, 520,000 prescriptions were issued for children under the age of 18 in 2002 alone. Of those, 13,800 were for infants and children aged between 2 and 6, and 2,750 were for infants under the age of 2 (30). Accumulating evidence suggests that the incidence and severity of articular cartilage injury in children treated with fluoroquinolones is markedly lower than that in animals $(31,32)$, suggesting that the side effects of fluoroquinolones are not be as serious as initially thought. Thus, the use of enoxacin to treat osteosarcoma in children may increase. Although osteosarcoma is common in people under the age of 20, as the global population grows and ages, the prevalence of osteosarcoma and other types of bone cancer will rise in the middle-aged and elderly (33). Enoxacin might become valuable in the treatment of these patient groups in the future.

The limitation of this study is that it only used a single cell line for experiments and further research is necessary in the future to verify the current findings.

Collectively, the present data demonstrated that enoxacin promotes apoptosis and inhibits proliferation, migration, and invasion of osteosarcoma 143B cells in vitro, and effectively impairs the growth of osteosarcoma in vivo. Based on these findings, enoxacin might represent a novel strategy for the treatment of osteosarcoma. However, its exact mechanism of action and clinical effects warrant further evaluation. 


\section{Acknowledgements}

Not applicable.

\section{Funding}

The present study was funded by the Key Research Plan of Jiangxi Province (grant no. 20171ACG70006) and National Natural Science Foundation of China (grant nos. 81860404, 81860405, 81601912 and 81660365).

\section{Availability of data and materials}

All data generated or analysed during the present study are included in the published article.

\section{Authors' contributions}

XWL, XQL, XLY, MD and TN designed the study. XWL, HXF, $\mathrm{BZ}$ and QYT performed in vivo experiments, while $\mathrm{XWL}$, FQW, ZPG, CY and FLL performed in vitro experiments and collected the data. XWL, XQL, CY, and TN analyzed the data. XWL and CY drafted the initial manuscript. XWL, HXF, BZ and MD instructed the experimental technology and critically reviewed the intellectual content of the article. All authors have read and approved the final manuscript.

\section{Ethics approval}

All animal studies were approved by the Ethics Committee of The First Affiliated Hospital of Nanchang University (Nanchang, China). All procedures were performed in accordance with the ethical standards of the institution or practice.

\section{Patient consent for publication}

Not applicable.

\section{Competing interests}

The authors declare that they have no competing interests.

\section{References}

1. Delebinski CI, Georgi S, Kleinsimon S, Twardziok M, Kopp B, Melzig MF and Seifert G: Analysis of proliferation and apoptotic induction by 20 steroid glycosides in 143B osteosarcoma cells in vitro. Cell Prolif 48: 600-610, 2015.

2. Liu SY, Deng SY, He YB and Ni GX: miR-451 inhibits cell growth, migration and angiogenesis in human osteosarcoma via down-regulating IL 6R. Biochem Biophys Res Commun 482: 987-993, 2017

3. Zhang J, Hou W, Chai M, Zhao H, Jia J, Sun X, Zhao B and Wang R: MicroRNA-127-3p inhibits proliferation and invasion by targeting SETD8 in human osteosarcoma cells. Biochem Biophys Res Commun 469: 1006-1011, 2016.

4. Isakoff MS, Bielack SS, Meltzer P and Gorlick R: Osteosarcoma: Current treatment and a collaborative pathway to success. J Clin Oncol 33: 3029-3035, 2015.

5. Gao JZ, Chen FH, Wang L, Wei H and Meng SL: YM155 inhibits tumor growth and enhances chemosensitivity to cisplatin in osteosarcoma. Eur Rev Med Pharmacol Sci 19: 2062-2069, 2015.

6. Brown HK, Tellez-Gabriel M and Heymann D: Cancer stem cells in osteosarcoma. Cancer Lett 386: 189-195, 2017.
7. Wise R, Andrews JM and Danks G: In-vitro activity of enoxacin (CL-919), a new quinoline derivative, compared with that of other antimicrobial agents. J Antimicrob Chemother 13: 237-244, 1984

8. Cao S, Sun R, Wang W, Meng X, Zhang Y, Zhang N and Yang S: RNA helicase DHX9 may be a therapeutic target in lung cancer and inhibited by enoxacin. Am J Transl Res 9: 674-682, 2017.

9. Mondal ER, Das SK and Mukherjee P: Comparative evaluation of antiproliferative activity and induction of apoptosis by some fluoroquinolones with a human non-small cell lung cancer cell line in culture. Asian Pac J Cancer Prev 5: 196-204, 2004.

10. Sousa E, Graça I, Baptista T, Vieira FQ, Palmeira C, Henrique R and Jerónimo C: Enoxacin inhibits growth of prostate cancer cells and effectively restores microRNA processing. Epigenetics 8: 548-558, 2013

11. Melo S, Villanueva A, Moutinho C, Davalos V, Spizzo R, Ivan C, Rossi S, Setien F, Casanovas O, Simo-Riudalbas L, et al: Small molecule enoxacin is a cancer-specific growth inhibitor that acts by enhancing TAR RNA-binding protein 2-mediated microRNA processing. Proc Natl Acad Sci USA 108: 4394-4399, 2011.

12. Bhanot SK, Singh M and Chatterjee NR: The chemical and biological aspects of fluoroquinolones: Reality and dreams. Curr Pharm Des 7: 311-335, 2001.

13. Sampo M, Koivikko M, Taskinen M, Kallio P, Kivioja A, Tarkkanen $M$ and Böhling T: Incidence, epidemiology and treatment results of osteosarcoma in Finland-a nationwide population-based study. Acta Oncol 50: 1206-1214, 2011.

14. Mirabello L, Troisi RJ and Savage SA: International osteosarcoma incidence patterns in children and adolescents, middle ages and elderly persons. Int J Cancer 125: 229-234, 2009.

15. Dai X, Ma W, He X and Jha RK: Review of therapeutic strategies for osteosarcoma, chondrosarcoma, and Ewing's sarcoma. Med Sci Monit 17: RA177-RA190, 2011.

16. Ando K, Heymann MF, Stresing V, Mori K, Rèdini F and Heymann D: Current therapeutic strategies and novel approaches in osteosarcoma. Cancers (Basel) 5: 591-616, 2013.

17. Lamoureux F, Trichet V, Chipoy C, Blanchard F, Gouin F and Redini F: Recent advances in the management of osteosarcoma and forthcoming therapeutic strategies. Expert Rev Anticancer Ther 7: 169-181, 2007.

18. Picci P: Osteosarcoma (osteogenic sarcoma). Orphanet J Rare Dis 2: 6, 2007.

19. Li Y, Liao Q, Li K, Zhong D, Weng X and Mi M: Knockdown of endothelin A receptor expression inhibits osteosarcoma pulmonary metastasis in an orthotopic xenograft mouse model. Mol Med Rep 5: 1391-1395, 2012.

20. Kato H, Wakabayashi H, Naito Y, Kato S, Nakagawa T, Matsumine A and Sudo A: Anti-tumor necrosis factor therapy inhibits lung metastasis in an osteosarcoma cell line. Oncology 88: 139-146, 2015.

21. Meazza C and Scanagatta P: Metastatic osteosarcoma: A challenging multidisciplinary treatment. Expert Rev Anticancer Ther 16: 543-556, 2016.

22. Shay G, Lynch CC and Fingleton B: Moving targets: Emerging roles for MMPs in cancer progression and metastasis. Matrix Biol 44-46: 200-206, 2015.

23. Jabłońska-Trypuć A, Matejczyk M and Rosochacki S: Matrix metalloproteinases (MMPs), the main extracellular matrix (ECM) enzymes in collagen degradation, as a target for anticancer drugs. J Enzyme Inhib Med Chem 31 (Suppl 1): S177-S183, 2016.

24. Zhu KP, Ma XL and Zhang CL: LncRNA ODRUL contributes to osteosarcoma progression through the miR-3182/MMP2 Axis. Mol Ther 25: 2383-2393, 2017.

25. Qiu R, Li X, Qin K, Chen X, Wang R, Dai Y, Deng L and Ye Y: Antimetastatic effects of calycosin on osteosarcoma and the underlying mechanism. Biofactors 45: 975-982, 2019.

26. Li J, Yang Z, Li Y, Xia J, Li D, Li H, Ren M, Liao Y, Yu S, Chen Y, et al: Cell apoptosis, autophagy and necroptosis in osteosarcoma treatment. Oncotarget 7: 44763-44778, 2016.

27. Silvestris F, Ribatti D, Nico B, Silvestris N, Romito A and Dammacco F: Apoptosis or programmed cell death: Regulatory and pathophysiological mechanisms. Ann Ital Med Int 10: 7-13, 1995 (In Italian).

28. Cardenas C, Montagna MK, Pitruzzello M, Lima E, Mor G and Alvero AB: Adipocyte microenvironment promotes $\mathrm{Bcl}_{\mathrm{xl}}$ expression and confers chemoresistance in ovarian cancer cells. Apoptosis 22: 558-569, 2017. 
29. Park SS, Lee DM, Lim JH, Lee D, Park SJ, Kim HM, Sohn S, Yoon G, Eom YW, Jeong SY, et al: Pyrrolidine dithiocarbamate reverses Bcl-xL-mediated apoptotic resistance to doxorubicin by inducing paraptosis. Carcinogenesis 39: 458-470, 2018.

30. Committee on Infectious Diseases: The use of systemic fluoroquinolones. Pediatrics 118: 1287-1292, 2006.

31. Hampel B, Hullmann R and Schmidt H: Ciprofloxacin in pediatrics: Worldwide clinical experience based on compassionate use-safety report. Pediatr Infect Dis J 16: 127-129, 160-162, 1997.
32. Bacci C, Galli L, de Martino M and Chiappini E: Fluoroquinolones in children: Update of the literature. J Chemother 27: 257-265, 2015.

33. Huvos AG: Osteogenic sarcoma of bones and soft tissues in older persons. A clinicopathologic analysis of 117 patients older than 60 years. Cancer 57: 1442-1449, 1986.

(7)(9) This work is licensed under a Creative Commons Attribution-NonCommercial-NoDerivatives 4.0 International (CC BY-NC-ND 4.0) License. 